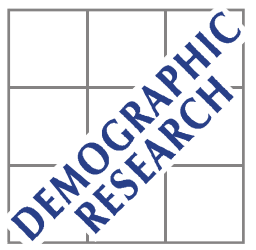

Demographic Research a free, expedited, online journal

of peer-reviewed research and commentary in the population sciences published by the Max Planck Institute for Demographic Research

Konrad-Zuse Str. 1, D-18057 Rostock · GERMANY

www.demographic-research.org

DEMOGRAPHIC RESEARCH

VOLUME 19, ARTICLE 55, PAGES 1851-1882

PUBLISHED 24 OCTOBER 2008

http://www.demographic-research.org/Volumes/Vol19/55/

DOI: $10.4054 /$ DemRes.2008.19.55

Research Article

Beyond denomination:

The relationship between religion and family planning in rural Malawi

\author{
Sara E. Yeatman \\ Jenny Trinitapoli
}

(C) 2008 Yeatman \& Trinitapoli.

This open-access work is published under the terms of the Creative Commons Attribution NonCommercial License 2.0 Germany, which permits use, reproduction \& distribution in any medium for non-commercial purposes, provided the original author(s) and source are given credit.

See http:// creativecommons.org/licenses/by-nc/2.0/de/ 


\section{Table of Contents}

1 Introduction 1852

2 Background 1852

2.1 Religion and contraceptive use in sub-Saharan Africa 1853

3 Hypotheses 1855

$4 \quad$ Data and methods 1859

4.1 Dependent variables 1859

$\begin{array}{ll}4.2 & 1860\end{array}$

5 The setting: rural Malawi 1864

5.1 Fertility and contraception in Malawi 1864

6 Results 1866

$\begin{array}{lll}7 & \text { Discussion } & 1873\end{array}$

8 Acknowledgements 1877

$\begin{array}{ll}\text { References } & 1878\end{array}$ 


\title{
Beyond denomination: The relationship between religion and family planning in rural Malawi
}

\author{
Sara E. Yeatman ${ }^{1}$ \\ Jenny Trinitapoli ${ }^{2}$
}

\begin{abstract}
Despite the centrality of religion and fertility to life in rural Africa, the relationship between the two remains poorly understood. The study presented here uses unique integrated individual- and congregational-level data from rural Malawi to examine religious influences on contraceptive use. In this religiously diverse population, we find evidence that the particular characteristics of a congregation-leader's positive attitudes toward family planning and discussion of sexual morality, which do not fall along broad denominational lines - are more relevant than denominational categories for predicting women's contraceptive use. We further find evidence for a relationship between religious socialization and contraceptive behavior.
\end{abstract}

\footnotetext{
${ }^{1}$ Assistant Professor, Department of Health and Behavioral Sciences, University of Colorado Denver. Tel: +1 303 556-3555. Fax: +1 303 556-8501. E-mail: sara.yeatman@ucdenver.edu.

${ }^{2}$ Assistant Professor, School of Social and Family Dynamics, Center for Population Dynamics, Arizona State University.
} 


\section{Introduction}

The AIDS epidemic in sub-Saharan Africa has prompted new discussions about the role of religious doctrine and religious institutions in shaping sexual behavior. By comparison, the importance of religion for other forms of reproductive behavior in the region has largely been neglected in recent years. Given that religion and fertility are two of the dominant characteristics of the rural African landscape, this omission is unfortunate - both theoretically and practically. Questions about how these two phenomena are related are central to developing better understandings of the cultural and demographic features and futures of the region.

In this paper, we ask how religion and religious involvement are associated with contraceptive behavior in rural Malawi. We draw on unique linked individual- and congregational-level data that allow us to move beyond the status-quo of demographic studies on religion and fertility, which has been to identify and explain differences in fertility and contraceptive use patterns between broad denominational categories. In focusing our attention at the congregational level - the level of direct interaction with both religious authority (leaders) and lay people (fellow congregation members) - we examine characteristics that are more relevant to the lives of rural Malawian women and more sociologically interesting for testing and improving theories of religious influence on reproductive behavior.

\section{Background}

Demographers have historically been interested in the relationship between fertility and religion in sub-Saharan Africa because of the region's high fertility and dynamic and influential religious environment. For example, John Caldwell and Pat Caldwell began their 1987 article with the statement: "Sub-Saharan Africa ${ }^{3}$ may well offer greater resistance to fertility decline than any other world region. The reasons are cultural and have much to do with a religious belief system that operates directly to sustain high fertility but that also has molded a society in such a way as to bring rewards for high fertility" (Caldwell and Caldwell 1987:409). They were not alone in this sentiment: religion was - and to an extent still is - seen largely as a barrier to fertility decline and to family planning adoption in the region.

Over the past two decades much has changed in the religious context of subSaharan Africa - new forms of Christianity and Islam have spread, evidenced by

${ }^{3}$ Caldwell and Caldwell talk about sub-Saharan Africa as a whole but most of their evidence is drawn from Nigeria in West Africa. 
dramatic growth in Pentecostalism and Arabicized Islam (Isichei 1995; Meyer 2004; Levtzion and Pouwels 2000). The reproductive context of the region has changed over the past twenty years as well. While fertility remains high compared to other parts of the world, modern family planning is widespread and the rewards for high fertility described by the Caldwells are no longer clear. How, in this new context, does religion - which is still vibrant and influential — affect fertility behavior?

McQuillan (2004) proposed three preconditions necessary for religion to influence fertility. He argued that religion will affect fertility behavior when it: (1) articulates norms relevant to fertility; (2) can communicate these values and promote compliance; and (3) is central to the social identity of its followers. In this paper, we argue that in rural Malawi these preconditions are met not at the broad level of denomination but rather at a more local level. In isolated communities, such as the rural villages of subSaharan Africa, norms are articulated by religious leaders and fostered within local congregations around which social identity develops.

Most demographic analyses of religious influences on fertility focus on the larger level of abstraction. In research on the West, this is beginning to change as studies increasingly incorporate measures of religiosity into fertility analyses (e.g., Hayford and Morgan 2008; Zhang 2008; Frejka and Westoff 2008; Adsera 2006a; Adsera 2006b). Still, few studies consider-or have the data to consider-local congregational influences. Research on religion and fertility in sub-Saharan Africa continues to focus almost exclusively on denominational differences (e.g., Gyimah et al. 2008; JohnsonHanks 2006; Agadjanian 2001; Gregson et al. 1999). While this may be intentional, it may also be due to the scarcity of regional data that goes beyond broad denominational categories. For example, the widely used Demographic and Health Surveys contain only a basic question on religious denomination and no questions on religiosity.

\subsection{Religion and contraceptive use in sub-Saharan Africa}

A long history of demographic research has identified the proximate determinants of fertility in populations to be: contraceptive use, abortion, postpartum insusceptibility (breastfeeding and abstinence), sexual exposure, fecundability and sterility (Bongaarts 1982). We focus our analysis on contraceptive use, as it is probably the most malleable of these proximate determinants, the easiest to measure, and has been widely regarded as the key determinant for the majority of worldwide fertility transitions (Frank and Bongaarts 1991; Notestein 1953). The adoption of contraception is a cultural process that depends on access to and acceptability of information (Agadjanian 2005), as well as contraceptives themselves. While access to contraception is likely unrelated to religion in rural sub-Saharan Africa, the acceptability of contraceptive use is related to 
one's faith or faith community. Traditional forms of contraceptive use (such as tying a string around one's waist) have a long history in the region (Kalipeni and Zulu 1993; Cohen 2000); however, the use of modern contraceptives (introduced in urban settings beginning in 1985) is still a reproductive innovation in rural Malawi. Despite a wealth of research describing prevalence of and patterns in the use of modern contraceptive methods in high-fertility settings such as sub-Saharan Africa, the role of a host of sociocultural factors (including religion) in facilitating or impeding the adoption of contraception remains only partially understood.

Previous studies on the relationship between religion and contraceptive use in subSaharan Africa provide a good background for our research although they often reach quite different conclusions. These studies consider religious influences on contraceptive attitudes and behavior, conceptualizing of religious influences as being denominationally-driven. Research in Ghana found that denominational differences in rural women's contraceptive use were entirely accounted for by differences in socioeconomic and demographic characteristics (Addai 1999). In contrast, other studies have found a more essential role for religion. For example, in rural Zimbabwe, Gregson and colleagues (1999) determined that the prohibitions against modern medicine and modern contraceptive use by strict Apostolic churches were significantly more salient than those from the Catholic Church, leading to lower contraception and higher fertility among Apostolics.

Anecdotal and empirical evidence from Muslims in other parts of the world has led researchers to expect Muslims in sub-Saharan Africa to have different contraceptive use patterns than others in their communities. Asian Muslims have more pro-natalist attitudes than their Christian counterparts (Morgan et al. 2002), and although Islam does not prohibit the use of contraception strictly speaking, some offer religious reasons for not using contraception (Caldwell and Barkat-e-Khuda 2000; Casterline et al. 2001). This does not, however, appear to be the case in sub-Saharan Africa. Population-level work in West Africa found that Muslims have lower fertility in areas where they are the majority group; contrarily, where they are in the minority, Muslims tend to have higher fertility levels that are mostly-but not entirely-accounted for by their lower socioeconomic status in such environments (Johnson-Hanks 2006). These patterns of fertility suggest no systematic difference at the denominational level in contraceptive use between Muslims and Christians in the region.

Work by Victor Agadjanian from Mozambique comes closest to providing explanations that consider factors "beyond denomination." Agadjanian (2001) found that Mission Protestants and Catholics in urban Mozambique were more likely to have used or had conversations about modern family planning than were women from "spirit-filled" or more evangelical churches. He argued that the urban religious setting of Mission Protestants and Catholics, in which churches tend to be large and diverse, 
facilitates interaction and mixing of women of different education levels, thus enabling social learning that is relevant to reproductive behavior. In these heterogeneous settings, women who were less likely to know of or use contraceptives came into contact with women who were well-versed in these technologies and subsequently adopted their behaviors. While religious effects in urban areas were specific to members of particular groups, in rural areas, on the other hand, any religious involvement was associated with increased contraceptive use and contraceptive dialogue. For these rural women, Agadjanian argued that attending religious services provided important social interaction within their congregation in what could otherwise be a quite isolated lifestyle where little new information was available.

This argument is, of course, a variant on the theory of diffusion, which has long played a critical if occasionally controversial role in theorizing about fertility decline and the spread of contraceptive use (Bongaarts and Watkins 1996; Cleland and Wilson 1987; Mason 1997). At an interpersonal level, social networks and the social interaction that they foster can have substantial influence on contraceptive behavior (Behrman; Kohler and Watkins 2002; Entwisle et al. 1996; Kohler 1997; Rutenberg and Watkins 1997). Agadjanian (2005) emphasizes the gendered process of social learning - information drawn upon by individuals when they weigh alternatives and make decisions (Montgomery and Casterline 1996) -- as being critical for contraceptive adoption in sub-Saharan Africa. Evidence from Malawi and Kenya has shown that women often engage in repeated discussions about family planning topics before drawing their own conclusions (Rutenberg and Watkins 1997; Paz Soldan 2004), whereas men are more likely to observe others and draw conclusions based on those observations (Paz Soldan 2004).

\section{Hypotheses}

We believe that the vibrant religious communities of rural Malawi influence the contraceptive behavior of individuals but not in the way typically theorized. In this paper, we test three hypotheses by examining the relationships between religion and contraceptive use at denominational, congregational, and individual levels.

\section{Hypothesis 1: Congregational leaders are more relevant than denominational edicts for shaping contraceptive use among lay women}

We anticipate that denominational influences-religious identities, specific doctrines or norms shared broadly - are less relevant to contraceptive behavior than are congregational influences. While denomination may serve as a rough proxy for the 
characteristics of one's congregation, especially when interacted with other key variables such as urbanicity, qualitative literature on religious life and practice in subSaharan Africa has shown wide variation within denominations (Trinitapoli 2006). The reliance on broad denominational categories is a notable limitation in the existing literature - as both a conceptual and methodological problem. Exploring associations at the congregational level offers a dramatic improvement over the industry standard. Aside from the uniquely designed dataset we employ, we know of no other data with this capacity.

In Malawi, as in the rest of rural sub-Saharan Africa, parishioners interact with the local representatives of their faith and with their fellow congregation members, while the positions of religious leaders in Lilongwe or Rome remain distant and largely irrelevant. Where literacy is low and Bibles and Korans are scarce, local religious leaders-ministers, priests and sheikhs-possess substantial authority in their communities on issues of doctrine, as well as on matters that extend beyond it. They provide counseling to their congregants on a range of issues spanning from matters directly related to faith to those further afield such as sexual morality and family life.

We hypothesize that what a religious leader believes and communicates will be associated with the fertility behavior of women in his congregation. We test this hypothesis by exploring the association between what a woman's congregational leader believes and says about family planning and sexual morality and her contraceptive use.

\section{Hypothesis 2: Religiously active women are more likely to contracept}

Despite wide recognition of the importance of religion in family life in the region, religious groups have largely been excluded from research on reproductive behavior and family planning in particular. We consider religious groups to include congregations at a broad level and what we call "extracurricular" religious activities such as choir and prayer groups that usually take place within congregations. We believe their neglect in the literature is primarily due to a deep-rooted assumption that religion and religious involvement are associated with "conservative" attitudes about issues surrounding family planning - including contraception - rather than "innovative" ones. While this seems to be true in the Western experience (Goldscheider and Mosher 1991; McQuillan 2004; Mosher and Hendershot 1984; Mosher et al. 1992; Williams and Zimmer 1990), in rural sub-Saharan Africa, religious groups are a main source of social engagement in an environment with limited opportunities. As the most common voluntary association (see Table 1), religious groups offer an ideal opportunity to examine these influences more closely. Outside of religious involvement, there are relatively few other sources of regular social interaction in rural Malawi, particularly for women. Men are more likely than women to engage in paid work and many spend 
time in bars, a space that is almost exclusively male. On the other hand, subsistence living generally necessitates that women's time is spent in the fields or over a cooking pot. While social interaction does, indeed, occur in these spaces, for example while fetching water from the borehole or shelling maize, it is generally limited to other women from the same household, compound, or village who likely have similar levels of education and similar experiences. In this context, religion provides one of the few social forums in which people of relatively diverse experiences come together on a regular basis.

Table 1: Involvement in secular and religious activities

\begin{tabular}{|c|c|c|c|}
\hline & & \multicolumn{2}{|c|}{ Participation, \% } \\
\hline & & Women & Men \\
\hline \multirow{4}{*}{ 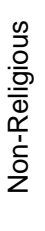 } & Farming cooperative & 27.3 & 47.3 \\
\hline & Health group & 8.0 & 13.9 \\
\hline & AIDS group & 3.7 & 10.8 \\
\hline & Credit group & 4.1 & 4.4 \\
\hline \multirow{10}{*}{ 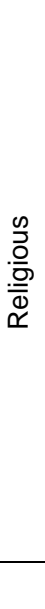 } & Weekly attendance & 61.9 & 65.3 \\
\hline & Prayer meeting & 26.9 & 28.7 \\
\hline & Visit sick & 25.9 & 23.1 \\
\hline & Elders meeting & 14.7 & 18.6 \\
\hline & Choir & 12.6 & 11.5 \\
\hline & Bible/Koran study & 9.1 & 14.4 \\
\hline & Revivals & 8.9 & 10.4 \\
\hline & Evangelism & 7.3 & 11.4 \\
\hline & Madrassa & 1.4 & 1.3 \\
\hline & $\mathrm{N}$ & 1609 & 1197 \\
\hline
\end{tabular}

Source: MDICP 2004 
We hypothesize that women who are involved in religious activities will be more likely to use contraceptives. We test this hypothesis by examining the relationship between religious attendance and involvement in extracurricular religious activities and contraceptive use.

\section{Hypothesis 3: Women in large congregations are more likely to contracept}

Religious congregations are a main source of social exposure for women in a context where opportunities for exposure to new ideas are constrained. Thus, we find Agadjanian's interaction hypothesis intuitively appealing. We expand upon it by incorporating Granovetter's theory (1973) on the strength of weak ties. Congregations in rural Malawi may provide one of the few opportunities for women to come into contact with women different from themselves. Participation in large congregations, in particular, likely fosters weak ties through which new information can be gleaned about a variety of things, including contraception-a topic about which strong ties are less likely to provide new information or sufficient experiences from which to learn. Kohler and colleagues (2001) found in Kenya that where the contraceptive market activity is high (i.e., where contraceptives are reasonably common), social learning was the dominant mechanism for spreading contraceptive knowledge. Similarly, Agadjanian (2005) emphasized the importance of social learning as being critical for contraceptive adoption in Mozambique. Social learning reduces the uncertainty associated with an innovation such as modern family planning and facilitates the evaluation of new information (Montgomery and Casterline 1996; Behrman et al. 2002).

We anticipate that women in larger congregations will be more likely to use contraception because they will have greater exposure to information about contraceptive use than women in smaller congregations where everyone knows each other and networks are homophilous.

Unlike previous studies, we extend our work to include the experiences of both Christians and Muslims. In his work, Agadjanian (2001) excludes Muslims (despite their making up 18 percent of the Mozambican population) because their religious participation differs measurably from Christians. However, there is little reason to believe that if the key operating mechanism relating religion and contraception in this context is interaction with one's leader and fellow congregants that it should differ for Muslims, even if their expression of religious involvement and how it is captured on surveys differs from Christian groups. Actually, if the relationships between religious involvement and contraceptive use operate similarly for groups as different as Pentecostals and Muslims, the case for the interaction hypothesis will be greatly strengthened 


\section{Data and methods}

The data for this analysis come from the Malawi Diffusion and Ideational Change Project (MDICP) ${ }^{4}$, an ongoing, longitudinal data collection project in rural Malawi that was designed to examine the role of social interactions in family planning, contraceptive decision-making, and the diffusion of knowledge about HIV and AIDS. The MDICP began in 1998 with a sample of 1500 ever-married women and their husbands (if currently married), using a cluster sampling strategy from 145 randomly selected villages in three rural districts. In 2004, an adolescent sample was added to the original sample. We use the third wave of the MDICP survey, which was collected in 2004 and contained questions about contraceptive use and an extensive module on religion and religious involvement. We combine this with unique data from the Malawi Religion Project (MRP) ${ }^{5}$, a sister project to the MDICP survey, which collected both in-depth interview and survey data in 2005 from the religious leaders of all MDICP respondents who were interviewed in 2004. Using unique congregation identifiers, we attach the characteristics of the congregation and leader (obtained through key informant interviews with religious leaders) to individual-level data from 2004. Finally, in assessing our hypotheses and interpreting the survey data, we draw loosely on three distinct types of qualitative data: (1) participant observation data collected from over 85 religious congregations in 2004 (Trinitapoli 2006), (2) in-depth interview data from a sub-sample of 111 lay female survey respondents conducted in the summer of 2005 centering around issues of religion, AIDS, and family planning, and (3) the authors' own field notes.

\subsection{Dependent variables}

We employ two complementary dependent variables drawn from the 2004 MDICP. The first is a dichotomous indicator of ever use of family planning and the second, a dichotomous indicator of current use of modern family planning. Respondents were asked if they had ever used family planning; if they answered in the affirmative they were subsequently asked if they were currently practicing family planning, and which method(s) they used. Women who responded that they currently used the pill, injectables, IUD or condoms were considered to be current users of modern family

\footnotetext{
${ }^{4}$ Malawi Diffusion and Ideational Change Project (PIs Susan Watkins, Hans-Peter Kohler and Jere Behrman). For more information, visit http://www.malawi.pop.upenn.edu/.

${ }^{5}$ Malawi Religion Project (PIs Susan Watkins). See Trinitapoli (2007) for a thorough description of these data.
} 
planning. There was not a specific response category for sterilization, but some women responded that they were using an "other" method and listed sterilization under this category. Sterilization is not a main method of contraception among this population ${ }^{6}$; nonetheless, some sterilized women were missed in this question and we acknowledge this as a limitation. Where possible, we focus on the use of modern family planning because modern contraception is an "innovation" in these rural communities and is thus more sociologically interesting for understanding the relationship between religion and contraceptive use. Although one could argue that effective use of traditional methods such as withdrawal could be considered innovative, traditional mechanisms of fertility control, particularly for birth spacing, have a longer history in the region and are less likely to be "learned" through interaction. Unfortunately, the data do not permit us to distinguish between women who have used any form of family planning and women who have used modern family planning when considering ever use. Modern family planning composes the vast majority of contraceptive use, making up almost 80 percent of current use of any method in the MDICP sample as well as in the 2004 DHS (Malawi National Statistical Office and ORC Macro 2005).

\subsection{Key independent variables}

The key independent variables of interest are the respondents' reports of religious affiliation and religious involvement and the characteristics of the specific congregation they attend, as reported by their religious leader. These variables fall into five categories.

Denomination: Respondents were asked their religious denomination in 2004. Based on their response, the interviewer assigned them to one of the following categories: No Religion, Catholic, Quadriya Muslim, Sukuti Muslim, Church of Central Africa Presbyterian (CCAP), Baptist, Anglican, Pentecostal, Seventh Day Adventist, Jehovah's Witness, Indigenous Christian, Indigenous Non-Christian, and Other. Respondents who answered "Other" were asked to further specify, and their answers were recorded verbatim and were subsequently grouped into the appropriate category by the second author. All respondents were also asked to name the church or mosque to which they belong. Respondents who were missing data on religious affiliation were categorized based on information gathered about the church or mosque they reported most frequently attending. After careful consideration, several denominational

\footnotetext{
${ }^{6}$ According to the 2004 Malawian DHS, 5.7 percent of married rural women were sterilized (Malawi National Statistical Office and ORC Macro 2005). Fewer women in our sample are likely sterilized because they live in very rural communities where there is limited access to a district hospital. The more accessible health clinics do not regularly offer tubal ligation or the less common vasectomy.
} 
categories were collapsed to a total of six categories used in this analysis: Catholic, Muslim, Pentecostal, African Independent Churches (AICs) ${ }^{7}$, Mission Protestant (e.g., Presbyterian, Anglican, and Baptist), and New Mission Protestant (e.g., Seventh Day Adventist, Church of Christ, and Jehovah's Witness).

Attendance: Attendance at religious services is a reliable and traditional measure of the public and collective expression of religion across many cultures and religious traditions. Our attendance measure was derived from the question: "When was the last time you went to church (or mosque)?" Respondents could answer with "in the last week," "in the last month," "last 2-6 months," "more than 6 months ago," or "never." More than 60 percent of the MDICP sample reported having attended religious services within the past week, while just 11 percent reported not having attended in the past month. Because our hypotheses hinge on regular participation in religious communities as spaces of routinized social interaction, we dichotomize this variable to separate the most regular attendees (last week) from all those who attend less frequently.

Religious activities: Religious involvement is, of course, not limited to attendance at main weekly services. Rural Malawians regularly participate in other religious activities such as prayer groups, Bible/Koran study groups, and choir. MDICP data are distinct in that they capture elements of the unique expression of religious involvement of Muslims as well as that of Christians. Respondents were asked: "What other religious activities have you done in the last month?" and were read the response categories which included: choir, elder's meeting, Bible/Koran study, prayer meeting, visiting the sick, revival meeting, evangelical work, Islamic school/madrasa, other and none. Responses (excluding none) were summed across the categories to create a single measure of the number of religious activities each respondent reports participating in.

We link MDICP data from 2004 to the religious leader data collected in 2005 to measure associations between individuals and their religious congregation. Three congregational-level variables are included in our analyses.

Religious leader: Religious leaders were asked about their views on modern family planning - specifically, whether or not they consider it acceptable to use modern family planning (1=acceptable). Leaders were also asked whether and how often they speak about sexual morality in religious services or sermons. This congregational-level variable was coded 1 for those who reported talking weekly about sexual morality and 0 for others.

Congregation size: The natural log of congregation size is included in the models to approximate heterogeneity within congregations. Larger congregations are more

\footnotetext{
${ }^{7}$ In Malawi, African Independent (or alternately, African Indigenous) Churches are most typically off-shoots from Mission Protestant congregations, the products of division over church practices and/or the integration of traditional culture (Jenkins 2002).
} 
likely to contain diversity of education, wealth, and exposure to health messages that might aid in the process of social learning.

We restrict our analysis of religious patterns in contraceptive use to women of child-bearing age (15-45). We include women from the original MDICP sample who were followed-up in 2004, as well as married adolescents from the 2004 refresher sample. Women were excluded from our analyses if they reported no religious affiliation ( $\mathrm{N}=33)$, could not be linked to a congregation $(\mathrm{N}=49)$, or had a missing value for religious leader's approval of modern family planning $(\mathrm{N}=41)$. Overall, our analytic sample includes 1122 ever-married women attending 150 different religious congregations.

We employ a series of control variables that are standard in studies of fertility and contraceptive use, including age, living children, years of education, and wealth (measured as an index of household goods). Table 2 presents means, standard deviations, and ranges of all individual- and congregational-level study variables. The three MDICP research sites reflect the ethnic, linguistic, and religious diversity of the country. Balaka District in the South is predominantly Muslim, while the other two sites are more religiously diverse but have few Muslims. Due to problems with colinearity between Muslims and Balaka District, we do not include a separate control for district in our analyses. Controlling for district does not, however, significantly change any of the relationships reported here, nor do they change substantially when analyses are run separately by district.

\section{Table 2: Descriptive statistics for variables of interest}

\begin{tabular}{lcccc}
\hline Variable & Mean & Std. Dev. & Min & Max \\
\cline { 1 - 2 } 2004 & & & & \\
\cline { 1 - 2 } DEPENDENT VARIABLES & & & 0 & 1 \\
Ever used family planning & 0.54 & & 0 & 1 \\
Currently using modern FP & 0.23 & & & \\
RELIGIOUS INVOLVEMENT & & & 1 & 3 \\
Attendance at regular religious services & 2.50 & 0.68 & 0 & 7 \\
Extra-curricular religious activities & 1.05 & 1.28 & 0 & 1 \\
Religious leader approves of modern FP & 0.80 & & & \\
\hline
\end{tabular}


Table 2: $\quad$ (continued)

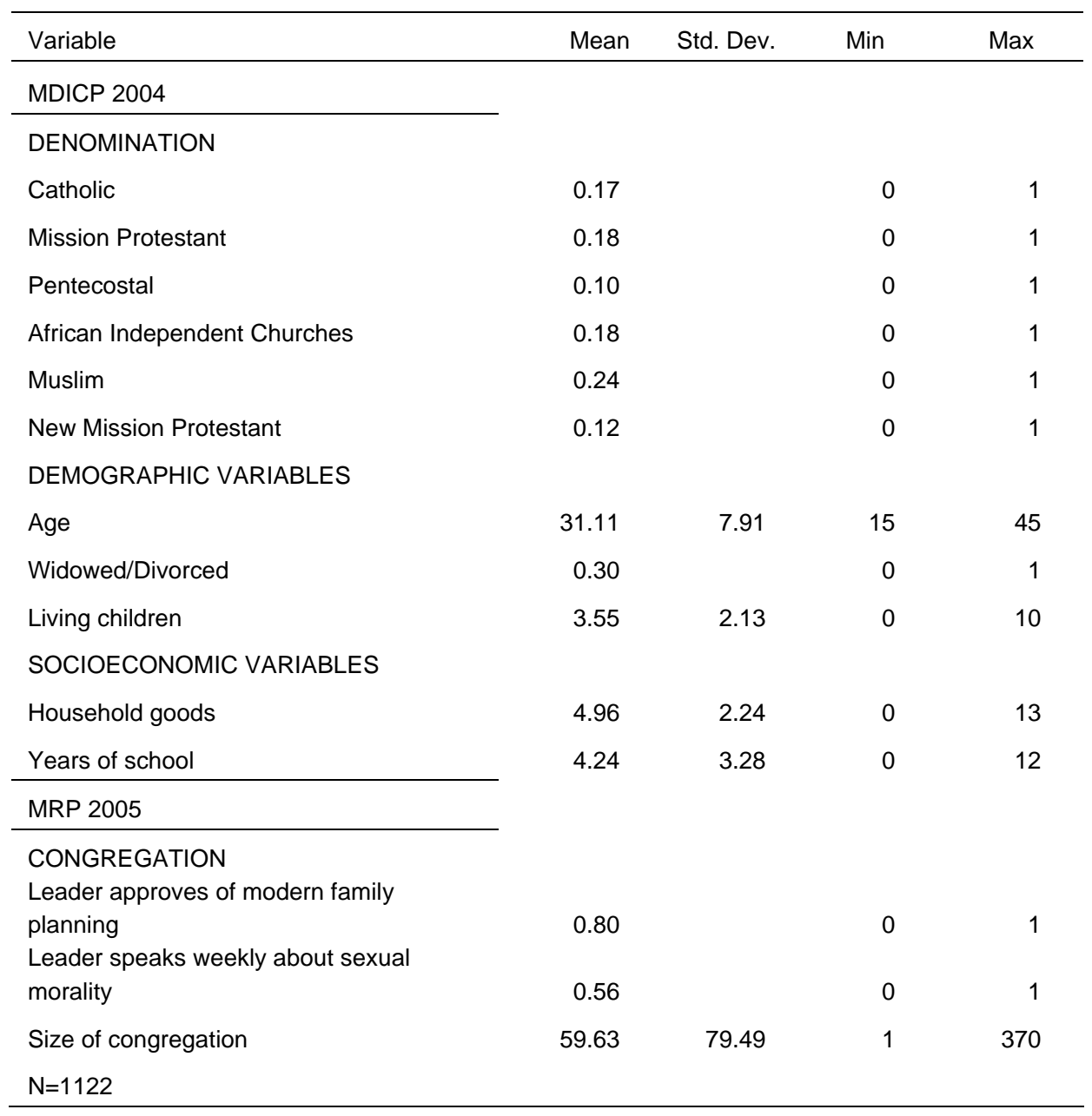

Source: MDICP 2004 
We begin by describing the setting of rural Malawi and our sample of individuals, congregations, and religious leaders. We then present a series of multivariate and multilevel logistic regression models designed to test each of the hypotheses examined here for the outcomes of interest - ever having used contraception and current use of a modern method. Because we are interested in the associations between congregationallevel characteristics and individual-level outcomes, we use Stata's xtlogit command to estimate simple two-level models that take into account the violation of the assumption of independence of observations, as some respondents attend the same religious congregation. Coefficients from the logistic regression models are converted to easily interpretable odds ratios for presentation in the tables. We conclude with a discussion of the implications of these findings and draw upon relevant qualitative data for these interpretations.

\section{The setting: rural Malawi}

Religion is ubiquitous in rural Malawi. Affiliation with a religious tradition is nearly universal and the majority attend religious services regularly and are involved in other religious activities such as choir groups or prayer groups that facilitate a sense of community within congregations (Trinitapoli and Regnerus 2006; Trinitapoli 2007). Most rural villages are spread out to accommodate subsistence agriculture and are generally composed of huts, boreholes, and churches and mosques. These religious buildings range from large Catholic Churches on main roads to three-sided buildings and even a mango tree where congregants have met regularly over a period of several years while raising money to build a permanent structure.

\subsection{Fertility and contraception in Malawi}

Although the fertility rate in Malawi has declined slightly in recent years, fertility remains high even for the region - the average Malawian woman will bear six children during her lifetime (Malawi National Statistical Office and ORC Macro 2005). Knowledge of contraception (traditional and modern) is widespread, and in 2004 twenty-seven percent of rural married women were using some form of modern contraception (Malawi National Statistical Office and ORC Macro 2005). Contraceptive use in rural areas is primarily intended to space children rather than limit the number of children (Cohen 2000; Lesthaeghe et al. 1981), and many women are still hesitant to use modern methods for fear of side effects, the discussion of which is quite common (Paz Soldan 2004). 
As a backdrop for an analysis of the association between religion and fertility behavior, we calculated the total fertility rate by denomination, including $95 \%$ confidence intervals ${ }^{8}$, using the 2004 Malawi Demographic and Health Survey (DHS, Figure 1). DHS data and sample size are ideal for documenting large-scale demographic changes (like fertility rates) but are not intended for conducting more thorough investigations of micro-demographic phenomena, such as the question of religious influences on fertility behavior. Denominational categories used by the DHS are not as precise as those we use in this analysis but do provide an interesting point of departure. Across Malawi as a whole, Muslim women have fertility rates that are a full child per woman higher than those of traditional Mission Protestants (here, Presbyterian and Anglican) $)^{9}$. "Other Christian" women have similarly high fertility, but it is difficult to determine who these women are. They are likely a mix of Pentecostal women and those belonging to African Independent Churches - two fairly distinct religious groups (Meyer 2004).

${ }^{8}$ We are grateful to Tom Pullum who created the program used to calculate these figures by subgroup.

${ }^{9} \mathrm{CCAP}$ and Anglicans are grouped together because of the similarity of these traditions in Malawi. However, Seventh Day Adventists and Baptists were grouped by DHS. 
Figure 1: Total fertility rate by religious affiliation

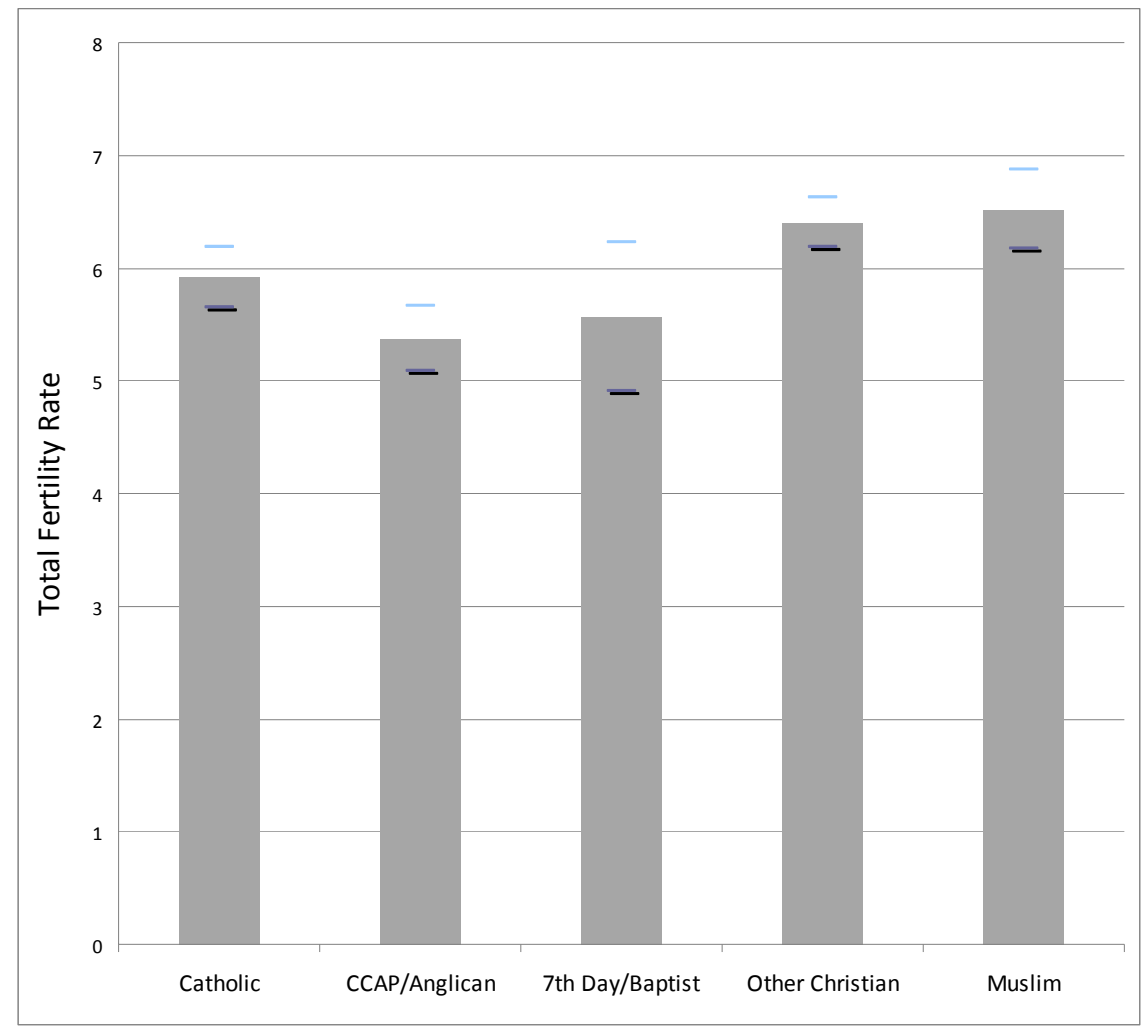

Source: Malawi 2004 DHS

\section{Results}

The MDICP sample accurately reflects Malawi's religious diversity; just under one quarter of respondents are Muslim, and there are also large representations of Catholics, Mission Protestants, and followers of African Independent Churches (Table 2). The two smallest denominational categories in our sample are Pentecostals and New Mission Protestants, both of which are newer to Malawi but growing in popularity. Religious involvement expands beyond weekly services on Sundays (for most Christians), Saturdays (for Seventh Day Adventists and Seventh Day Baptists) or Fridays (for 
Muslims) - there are choir groups, prayer groups, study groups, revivals, and regional meetings, in which women interact with other women on a regular or semi-regular basis. Many of these activities such as prayer and choir groups bring rural Malawian women into contact with others who are similar (e.g., share their religious faith and live within walking distance of the same congregation); however, other activities such as regional meetings and revivals facilitate contact with women who are different in key dimensions (e.g., more educated, employed outside of the home or of a different denomination $\left.{ }^{10}\right)$.

Table 1 above shows the prevalence of participation in religious activities compared with participation in other (secular) organizations by gender. Men are more active in all types of non-religious social groups than are women, for whom religious activities are the dominant source of regular social interaction. Apart from farming cooperatives in which a quarter of women participate, religious activities such as attending services, participating in prayer groups, and visiting the sick are the most common activities for women. Overall, 57 percent of MDICP women participate in at least one of these extracurricular religious activities. Participation in extracurricular religious activities is highest among Pentecostal and Catholic women, while few Muslim and New Mission Protestant women participate in such activities on a regular basis (Figure 2).

\section{Figure 2: $\quad$ Participation in extracurricular religious activities} by religious affiliation

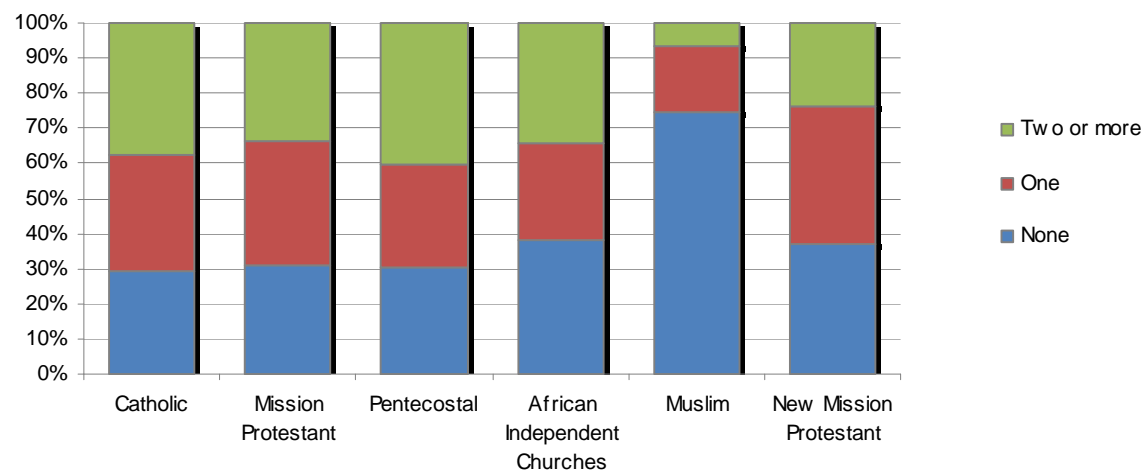

Source: MDICP 2004

${ }^{10}$ Although likely belonging to the same religious tradition broadly speaking, such as Presbyterian and Holy Cross -- both Christian. 
Support for modern family planning is high among religious leaders overall: nearly 80 percent of leaders in the sample report that the use of modern family planning is acceptable (Table 3). Catholic religious leaders are the least likely to endorse (or tolerate) this practice. Nonetheless, the acceptability of modern family planning among Catholic leaders is remarkably high (60 percent) considering that the Catholic Church hierarchy intends for it to be universally unacceptable. Interestingly, attitudes about contraception among Catholic leaders do not differ significantly from those of Mission Protestant leaders such as Anglicans and Baptists who are under no such directive. Modern family planning is almost unanimously considered acceptable by Pentecostal and Muslim leaders.

Table 3: Characteristics of religious leaders and congregations by denomination

\begin{tabular}{lcccc}
\hline & $\begin{array}{c}\text { Modern FP } \\
\text { Acceptable, } \%\end{array}$ & $\begin{array}{c}\text { Sexual Morality } \\
\text { Weekly, \% }\end{array}$ & $\begin{array}{c}\text { Congregation } \\
\text { Size, mean (SD) }\end{array}$ & N \\
\hline Catholic & 63 & 47 & $36(43)$ & 19 \\
Mission Protestant & 66 & 58 & $34(52)$ & 38 \\
Pentecostal & 90 & 39 & $26(27)$ & 31 \\
African Independent & 84 & 55 & $31(28)$ & 38 \\
Churches & 91 & 41 & $76(101)$ & 22 \\
Muslim & 74 & 44 & $36(43)$ & 34 \\
New Mission & 78 & 48 & $37(52)$ & 182 \\
Protestant & & &
\end{tabular}

Source: MRP 2005

Consistent with previous research (Trinitapoli 2006; Pfeiffer 2004), the MRP data show that religious leaders in rural Malawi speak regularly about sexual morality in weekly religious services; indeed, just under half of religious leaders in this sample reported that they specifically talk about sexual morality in religious services or sermons every week (Table 3). A small minority of these leaders (five percent) report never talking about it. The discussion of sexual morality in religious services is regular and common across denominations. Mission Protestant and African Independent Church leaders report the most consistent inclusion in their weekly services while Pentecostal and Muslim leaders report the least. Those who speak regularly about sexual morality and those who speak less frequently do not substantially differ in their 
responses to questions about sex, gender roles, and family planning. In other words, those who make a point of bringing up sexual morality weekly hold broadly similar beliefs on related topics from those who do not; they differ only in the importance they place on incorporating issues of sexuality into their services.

Religious congregations in rural Malawi vary in size from 10 persons ( 1 or 2 families) to over 200, even in rural areas. The mean congregation size for Christian congregations in the sample fell between 26 and 36 regularly attending adults members; mosque leaders, in contrast, reported an average of 76 adults attending Friday services. The similarity among Christian congregations when considered by denomination masks the great differences among the individual congregations themselves, as congregations with more than 100 regularly attending adults were found within each denomination.

Family planning use is widespread among rural Malawian women. Fifty four percent of ever-married women have used family planning and 23 percent currently use modern family planning (Table 2). Denominational patterns of contraceptive use among women differ dramatically from the stated positions of leaders in these traditions. Both ever use and current use of modern family planning are highest among Catholics, New Mission Protestants, and Mission Protestants, and lowest among Muslims (Figures 3 and 4). In fact, denominational patterns of contraceptive use among women are nearly exactly opposite the stated positions of religious leaders.

\section{Figure 3: Ever use of family planning by religious affiliation}

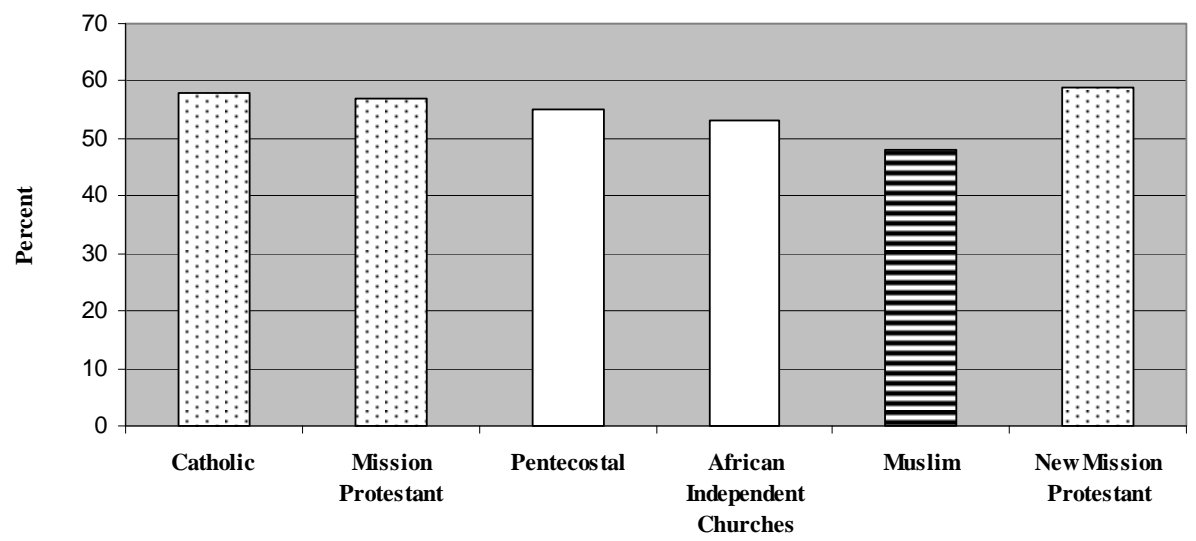

Source: MDICP 2004

Dotted bars significantly different from striped bar at $p<.10$ level 
Figure 4: Current use of modern family planning by religious affiliation

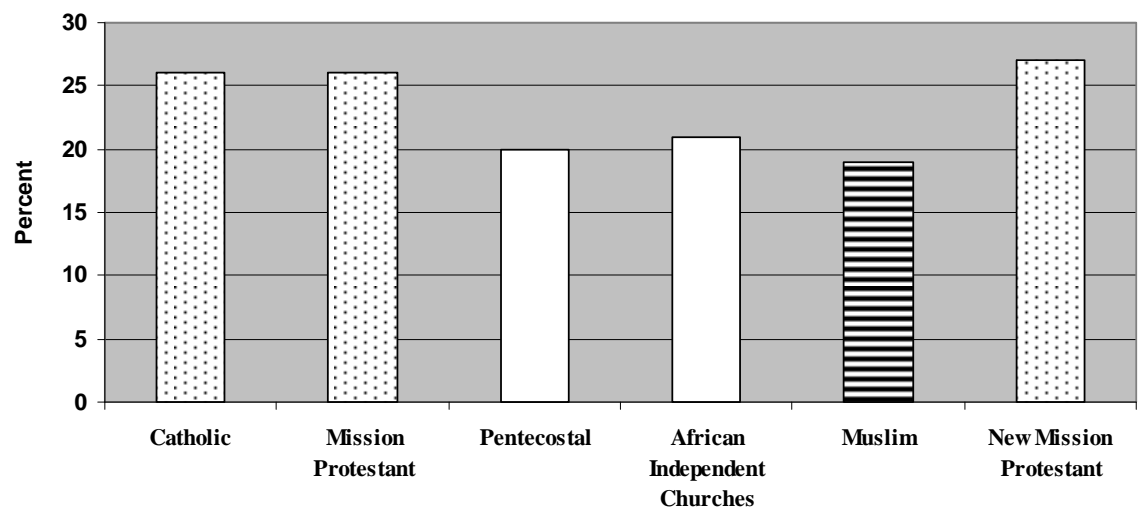

Source: MDICP 2004

Dotted bars significantly different from striped bar at $p<0.10$ level

Multilevel logistic regression models allow for a closer examination of religious patterning in contraceptive use and the association between individual behavior and congregational-level influences. Table 4 presents models predicting ever use of family planning. The addition of sociodemographic controls in Model 1 eliminates the significant bivariate differences (Figure 3) observed between Muslims and other groups (specifically Catholics, Mission Protestants and New Mission Protestants). Consistent with the wealth of literature on family planning, socioeconomic status (household goods), number of surviving children, and education are all positively associated with family planning, and there is a curvilinear relationship with age. The addition of two measures of religious involvement in Model 2-attendance at religious services and involvement in other religious activities - reveals no significant associations, suggesting that current socialization does not provide a compelling explanation for variation in family planning use over the course of a woman's life, as captured in the "ever use" measure. The third model adds the three congregational-level variables ${ }^{11}$ and reveals a strong positive association between religious leader's approval of modern family planning and a woman in his congregation having used contraception. Compared to women who attend congregations in which the leader says that modern family planning is unacceptable, women in congregations led by individuals who accept modern family planning have 80 percent greater odds of having contracepted. Similarly, 11 The models were also run adding each congregation-level variable separately because of concerns about
colinearity. The results were consistent with both modeling approaches. 
women in congregations where the leader speaks frequently about sexual morality are more likely to have used contraception. Finally, women in larger congregations are more likely to have used contraception.

Table 4: Exponentiated regression coefficients predicting ever use of family planning

\begin{tabular}{|c|c|c|c|}
\hline & Model 1 & Model 2 & Model 3 \\
\hline \multicolumn{4}{|l|}{ Denomination (vs Catholic) } \\
\hline Mission Protestant & 0.87 & 0.87 & 1.06 \\
\hline Pentecostal & 0.97 & 0.97 & 1.13 \\
\hline African Independent Churches & 0.88 & 0.88 & 0.91 \\
\hline Muslim & 0.99 & 0.97 & 0.84 \\
\hline New Mission Protestant & 1.18 & 1.17 & 1.38 \\
\hline Age (25-34) & $1.42+$ & $1.41+$ & 1.47 * \\
\hline Age $(35+)$ & 0.86 & 0.86 & 0.87 \\
\hline Children Ever Born (alive) & 1.28 ** & 1.29 ** & 1.28 ** \\
\hline Household Goods & 1.09 * & 1.09 * & 1.08 * \\
\hline Secondary Education & $1.05+$ & $1.05+$ & 1.05 * \\
\hline Previously Married & 1.01 & 1.00 & 1.00 \\
\hline Attendance at Religious Services & & 1.01 & 1.00 \\
\hline Religious Activities & & 0.98 & 0.98 \\
\hline Leader approves of modern FP use & & & $1.80 * *$ \\
\hline Leader discusses sexual morality weekly & & & $1.32+$ \\
\hline Size of congregation (logged) & & & 1.16 * \\
\hline$\chi^{2}$ & 67.17 & 67.26 & 80.57 \\
\hline AIC & 1491.32 & 1495.20 & 1483.36 \\
\hline $\mathrm{N}$ & 1122 & 1122 & 1122 \\
\hline
\end{tabular}

$+p<0.10 * p<0.05 * * p<0.01$

Source: MDICP 2004 \& MRP 2005 
Yeatman \& Trinitapoli: Religion and family planning in rural Malawi

Table 5: Exponentiated regression coefficients predicting current use of modern family planning

\begin{tabular}{|c|c|c|c|}
\hline & Model 1 & Model 2 & Model 3 \\
\hline \multicolumn{4}{|l|}{ Denomination (vs Catholic) } \\
\hline Traditional Mission Protestant & 0.88 & 0.89 & 1.04 \\
\hline Pentecostal & 0.72 & 0.71 & 0.84 \\
\hline African Independent Churches & 0.85 & 0.87 & 0.93 \\
\hline Muslim & 1.07 & 1.17 & 1.03 \\
\hline New Mission Protestant & 1.13 & 1.14 & 1.29 \\
\hline Age (25-34) & 1.11 & 1.10 & 1.13 \\
\hline Age $(35+)$ & 0.56 * & 0.56 * & 0.56 * \\
\hline Children Ever Born (alive) & $1.19 * *$ & $1.20 * \star$ & 1.20 ** \\
\hline Household Goods & $1.07+$ & $1.07+$ & $1.07+$ \\
\hline Secondary Education & $1.08 * *$ & 1.08 ** & 1.09 ** \\
\hline Previously Married & $0.69 *$ & 0.69 * & 0.69 * \\
\hline Attendance at Religious Services & & $1.31+$ & $1.32+$ \\
\hline Religious Activities & & 1.03 & 1.03 \\
\hline Leader approves of modern FP & & & 1.35 \\
\hline Leader discusses sexual morality weekly & & & 1.38 * \\
\hline Size of congregation (logged) & & & 1.20 * \\
\hline$\chi^{2}$ & 47.36 & 50.50 & 60.64 \\
\hline AIC & 1179.55 & 1179.91 & 1173.63 \\
\hline $\mathrm{N}$ & 1122 & 1122 & 1122 \\
\hline
\end{tabular}

$+\mathrm{p}<0.10{ }^{*} \mathrm{p}<0.05 * \star \mathrm{p}<0.01$

MDICP 2004 \& MRP 2005 
Table 5 applies the same modeling strategy to predict current use of modern family planning. At the bivariate level (see Figure 4), Muslims are the least likely to use injectables, pills, IUDs or condoms; but, as with ever use, Muslim differentials are explained by differences in sociodemographic composition. Model 2 adds the two measures of religious involvement. Women who attend religious services weekly are more likely to use modern contraception than those who do not; however, contrary to our expectations, there is no relationship between extracurricular religious activities and current contraceptive use. Model 3 shows that a religious leader's approval of modern contraceptive use operates in the predicted direction but is not significantly associated with women's behavior. Women in congregations where the leader speaks regularly about sexual morality, however, are more likely to be using modern contraception, as are women in larger congregations.

\section{Discussion}

After accounting for compositional differences, there are no denominational differences in contraceptive use in rural Malawi. This finding suggests that in this part of the world religion does not influence contraceptive patterns through top-down denominational edicts. Had we limited our conceptualization of religious influences to denomination, we might conclude that religion plays little role in contraceptive use. However, by taking a more comprehensive view of what religion means locally, we find strong relationships between religion and contraception in rural Malawi.

Consistent with Hypothesis 1, we find that congregational characteristics are indeed more relevant than denominational ones. The majority of leaders of all faiths approve of the use of modern family planning. Catholic leaders are least likely to approve and Pentecostal and Muslim leaders are the most likely to approve of such practices. The actual behavior of women within denominations, however, operates in the opposite direction-Catholic women are among the most likely to use contraception and Muslim and Pentecostal women are among the least likely. At the ecological level, this relationship suggests little connection between the positions of local religious leaders and the contraceptive behavior of their membership. By looking specifically at congregational-level associations, however, we find that what individual leaders believe is strongly associated with the family planning practices of the women in their own congregations. The clearest association exists between what a leader believes and his congregants ever having used family planning. This suggests a more indirect relationship between what a leader believes and what a congregant chooses to do. 
Qualitative data ${ }^{12}$ from participant observation of religious services show that leaders rarely mention family planning during sermons; across denominations, they are neither encouraging women to "multiply like sand" nor promoting modern contraceptive use from the pulpit.

Rather, there are other ways to explain the association. It is possible that leaders privately counsel members on issues such as childbearing and family planning. Men and women often seek counseling from their religious leaders on marriage and family, and it is conceivable that leaders offer guidance on topics such as family size or sexual practices, which are closely related to their own beliefs about family planning. It is equally possible that these findings simply reflect that religious leaders are first and foremost members of their communities and on topics that are not directly religious they share the beliefs of other community members more than the beliefs of their denominational authorities. In fact, nearly two-thirds of Catholic leaders approve of modern family planning in spite of the well-known admonishments by the Church hierarchy. In a dynamic religious market such as that of rural Malawi, it is further possible that religious leaders adapt their teaching towards prevailing norms in their communities and family size and family planning are considered more "secular" concerns than other issues of sexuality on which they are more likely to lead. In the context of rural sub-Saharan Africa many of these ostensibly hierarchical churches and mosques are quite geographically isolated despite the formalized structure of the denomination to which they belong. That many are out of step with the formal teachings of their denominational authorities indicates a significant level of effective isolation from directives on the topic of contraception.

Consistent with findings from studies of the role of religion in HIV prevention, we find that many leaders regularly discuss issues of sexual morality at religious services. Though particularly salient among the nineteenth century Christian missionaries whose early efforts focused sharply on discouraging polygamy, female genital cutting, and very early marriage, the regulation of "African" sexual practices has been a central theme of both Christian and Muslim missionary endeavors in the region for centuries. More recently, the scope of the AIDS epidemic has increased the practical relevance of these topics, heightening the imperative of addressing matters of sex and family formation in mixed settings like religious services, where such issues may, for a time, have been considered inappropriate (Trinitapoli 2006).

Our analyses show that female congregants who attend congregations in which topics of sexual morality are frequently discussed do more to regulate their fertility than women who attend congregations where there is comparative silence on these issues. We believe that these congregations - the ones in which matters of sexuality are

\footnotetext{
${ }^{12}$ See Trinitapoli (2006) for a description of the participant observation data from religious sermons.
} 
discussed on a regular basis - represent a unique type of space that facilitates the exchange of information on matters related to sex and reproduction that might have crucial implications for a variety of demographic phenomena. We emphasize that the mechanism by which religion influences contraceptive use and subsequent fertility for women is likely not through the specific discussion of contraceptives in religious services. Rather, we interpret these findings as evidence that women in congregations where leaders talk openly about sexual morality from the pulpit may be more likely to discuss issues related to sex and contraception with other members; thereby garnering crucial pieces of information they can use to navigate their own reproductive futures. For example, information about the reliability of modern contraceptives, potential side effects, and where to access them are unlikely to flow from male leader to female members in the setting of rural Malawi. However, this type of information might circulate freely among women who attend congregations in which sexual matters are "on the table" for discussion. Combined with evidence of distinctive patterns of reported sexual behavior among members of congregations in which sexual morality is discussed frequently (Trinitapoli 2007), membership in these spaces of "sexual dialogue" may have far-reaching health implications for both individuals and for entire families.

In the United States, religious engagement and strength of religious belief have been shown to be good predictors of fertility behavior: those who are more religious have higher fertility and are less likely to use contraception (Hayford and Morgan 2008; Zhang 2008; Brewster et al. 1998; Goldscheider and Mosher 1991). In rural Malawi, however, weekly attendance at religious services is positively associated with the use of modern contraceptives. We find some support for our second hypothesis: women who regularly attend religious services are somewhat more likely to use modern contraceptives than those who attend less frequently; however, involvement in other extracurricular religious activities was not associated with contraceptive behavior. Since religious leaders are not speaking specifically about family planning and only vaguely about family building, the relationship between attendance and contraceptive use may instead reflect a women's engagement in her religious community. In a context where upwards of 90 percent of women identify with not just a denomination but also a specific religious congregation, women who attend regularly are better woven into the social fabric of their community and, thus, are more likely to engage in discussionssome about family planning-with other parishioners. We know that religious communities develop around social networks in addition to religious beliefs (Smilde 2005; Stark and Finke 2000). In a context with limited outlets for participation in civic life, religious communities offer regularized social interaction, leading to exposure to new ideas and facilitating the process of social learning. 
This ties closely with the finding - consistent with Hypothesis 3-that women in larger congregations, where the possible interactions are more varied, are more likely to have used contraception and to be currently using modern contraception. Large congregations are good sources of weak ties, which are important for social learning about family planning: they provide forums for regular interaction among heterogeneous women. Unlike small congregations where dense networks would constrain access to new information, large congregations consist of sparse networks and thus opportunities for the diffusion of information and practices related to family planning use.

It is possible that the relationship between contraceptive use and various measures of socialization operate, to some extent, in the reverse direction to the one we have suggested. Women who are continually pregnant or have closely spaced children are less likely to have the time to attend religious services or activities ${ }^{13}$. As one Muslim woman interviewed as part of the Malawi Religion Project stated: "When you practice family planning, you have a lot of time for meetings." However, controls added for age and parity should limit the possibility that this phenomenon is actually driving the findings we report here, and the theoretical frameworks we draw upon privilege the explanation that women use the opportunities for interaction created by religion to discuss families and family planning with women outside of their kin networks as the more plausible one.

To the extent that religion does influence contraceptive behavior in sub-Saharan Africa, we still have much to learn about how and why. Our findings point to the supraindividual quality of religion, which, as it shapes social behaviors, is a complicated mechanism that extends beyond the simple measures of individual-level affiliation and religiosity. They also identify a strong intra-denominational influence - where a leader's approval and the opinion of other women in the congregation can shape or be shaped through repeated interaction.

This study further emphasizes the importance of regularly collecting religious data that go beyond broad denominational categories in sub-Saharan Africa. While few surveys will have the resources to link religious leaders to their congregants, as we have done here, religion and demographic phenomena are closely associated in the region, and the potential interpretive payoff of including questions on religiosity and selfreported descriptions of congregations would be considerable.

${ }^{13}$ In the West, there is evidence that childbearing leads to higher religious attendance (Stolzenburg et al. 1995). However, in a high fertility context like Malawi we consider the opposite more plausible. 


\section{Acknowledgements}

Data from the Malawi Diffusion and Ideational Change Project were supported by grants from the Rockefeller Foundation, NICHD (R01-HD41713, R01-HD373-276); NIA (AG1236-S3); and the Center for AIDS Research and the Center on the Demography of Aging, both at the University of Pennsylvania. Data from the Malawi Religion Project were supported by a grant from NICHD (R01-HD050142-01). Both authors were partially supported during this research by a grant from NICHD (R01HD050142-01) and an NICHD training grant (T32 HD07081-27) through the Population Research, University of Texas at Austin. An earlier version of this paper was presented at the 2007 Annual Meetings of the Population Association of America in New York City. 


\section{References}

Addai, I. (1999). Does religion matter in contraceptive use among Ghanaian women? Review of Religious Research 40(3): 259-277.

Adsera, A. (2006a). Marital fertility and religion in Spain, 1985 and 1999. Population Studies 60(2): 205-221.

Adsera, A. (2006b). Religion and changes in family-size norms in developed countries. Review of Religious Research 47(3): 271-286.

Agadjanian, V. (2005). Gender, religious involvement, and HIV/AIDS prevention in Mozambique. Social Science \& Medicine 61(7): 1529-1539.

Agadjanian, V. (2001). Religion, social milieu, and the contraceptive revolution. Population Studies 55(1): 135-148.

Behrman, J.R., Kohler, H.-P. and Watkins, S.C. (2002). Social networks and changes in contraceptive use over time: Evidence from a longitudinal study in rural Kenya. Demography 39(4): 713-738.

Bongaarts, J. (1982). The fertility-inhibiting effects of the intermediate fertility variables. Studies in Family Planning 13(6/7): 179-189.

Bongaarts, J. and Watkins, S.C. (1996). Social interactions and contemporary fertility transitions. Population and Development Review 22(4): 639-682.

Brewster, K.L., Cooksey, E.C., Guilkey, D.K. and Rindfuss, R.R. (1998). The changing impact of religion on the sexual and contraceptive behavior of adolescent women in the United States. Journal of Marriage and the Family 60(2): 493504.

Caldwell, B. and Barkat-e-Khuda. (2000). The first generation to control family size: A microstudy of the causes of fertility decline in a rural area of Bangladesh. Studies in Family Planning 31(3): 239-251.

Caldwell, J.C. and Caldwell, P. (1987). The cultural context of high fertility in subSaharan Africa. Population and Development Review 13(3): 409-437.

Casterline, J.B., Sathar, Z.A. and Haque, M.u. (2001). Obstacles to contraceptive use in Pakistan: A study in Punjab. Studies in Family Planning 32(2): 95-110.

Cleland, J. and Wilson, C. (1987). Demand theories of the fertility transition - An iconoclastic view. Population Studies 41(1): 5-30. 
Cohen, B. (2000). Family planning programs, socioeconomic characteristics, and contraceptive use in Malawi. World Development 28(5): 843-860.

Entwisle, B., Rindfuss, R.R., Guilkey, D.K., Chamratrithirong, A., Curran, S.R. and Sawangdee, Y. (1996). Community and contraceptive choice in rural Thailand: A case study of Nang Rong. Demography 33(1): 1-11.

Frank, O. and Bongaarts, J. (1991). Behavioural and biological determinants of fertility transition in sub-Saharan Africa. Statistics in Medicine 10(2): 161-175.

Frejka, T. and Westoff, C.F. (2008). Religion, religiousness and fertility in the US and in Europe. European Journal of Population 24(1): 5-31.

Goldscheider, C. and Mosher, W.D. (1991). Patterns of contraceptive use in the UnitedStates: The importance of religious factors. Studies in Family Planning 22(2): 102-115.

Granovetter, M. (1973). The strength of weak ties. American Journal of Sociology 78(6): 1360-1380.

Gregson, S., Zhuwau, T., Anderson, R.M. and Chandiwana, S.K. (1999). Apostles and Zionists: The influence of religion on demographic change in rural Zimbabwe. Population Studies 53(2): 179-193.

Gyimah, S.O., Takyi, B. and Tenkorang, E.Y. (2008). Denominational affiliation and fertility behaviour in an African context: An examination of couple data from Ghana. Journal of Biosocial Science 40(3): 445-458.

Hayford, S.R. and Morgan, S.P. (2008). Religiosity and fertility in the United States: The role of fertility intentions. Social Forces 86(3): 1163-1188.

Isichei, E. (1995). A history of christianity in Africa: From antiquity to the present. Grand Rapids: Eerdmans.

Jenkins, P. (2002). The next christendom: The coming of global christianity. Oxford: Oxford University Press.

Johnson-Hanks, J. (2006). On the politics and practice of Muslim fertility: Comparative evidence from West Africa. Medical Anthropology Quarterly 20(1):12-30.

Kalipeni, E. and Zulu, E.M. (1993). Gender differences in knowledge and attitudes toward modern and traditional methods of child spacing in Malawi. Population Research and Policy Review 12(2): 103-121.

Kohler, H.-P. (1997). Learning in social networks and contraceptive choice. Demography 34(3): 369-383. 
Kohler, H.-P., Behrman, J.R. and Watkins, S.C. (2001). The density of social networks and fertility decisions: Evidence from South Nyanza District, Kenya. Demography 38(1): 43-58.

Lesthaeghe, R., Ohadike, P.O., Kocher, J. and Page, H.J. (1981). Child-spacing and fertility in sub-Saharan Africa: An overview of issues. In: Page, H.J. and Lesthaeghe, R. (eds.). Child-spacing in tropical Africa: Traditions and change. London: Academic Press: 3-23.

Levtzion, N. and Pouwels, R.L. (eds.). (2000). The history of Islam in Africa. Athens: Ohio University Press.

Malawi National Statistical Office and ORC Macro. (2005). Malawi Demographic and Health Survey 2004. Calverton: NSO and ORC Macro.

Mason, K.O. (1997). Explaining fertility transitions. Demography 34(4): 443-454.

McQuillan, K. (2004). When does religion influence fertility? Population and Development Review 30(1): 25-56.

Meyer, B. (2004). Christianity in Africa: From African independent to pentecostalcharismatic churches. Annual Review of Anthropology 33(1): 447-474.

Montgomery, M.R. and Casterline, J.B. (1996). Social learning, social influence, and new models of fertility. In: Casterline, J.B., Lee, R.D. and Foote, K.A. (eds.). Fertility in the United States: New patterns, new theories. New York: Population Council: 151-175 (Population and Development Review; 22.1996, Suppl.).

Morgan, S.P., Stash, S., Smith, H.L. and Mason, K.O. (2002). Muslim and non-Muslim differences in female autonomy and fertility: Evidence from four Asian countries. Population and Development Review 28(3): 515-537.

Mosher, W.D. and Hendershot, G.E. (1984). Religion and fertility: A replication. Demography 21(2): 185-191.

Mosher, W.D., Williams, L.B. and Johnson, D.P. (1992). Religion and fertility in the United States: New patterns. Demography 29(2): 199-214.

Notestein, F. (1953). Economic problems of population change. In: Proceedings of the Eighth International Conference of Agriculture Economists: Held at Kellogg Center, Michigan State College USA, 15-22 August 1952. London: Oxford University Press: 13-31.

Paz Soldan, V.A. (2004). How family planning ideas are spread within social groups in rural Malawi. Studies in Family Planning 35(4): 275-290. 
Pfeiffer, J. (2004). Civil society, NGOs, and the holy spirit in Mozambique. Human Organization 63(3): 359-372.

Rutenberg, N. and Watkins, S.C. (1997). The buzz outside the clinics: Conversations and contraception in Nyanza Province, Kenya. Studies in Family Planning 28(4): 290-307.

Smilde, D. (2005). A qualitative comparative analysis of conversion to Venezuelan evangelicalism: How networks matter. American Journal of Sociology 111(3): 757-796.

Stark, R. and Finke, R. (2000). Acts of faith: Explaining the human side of religion. Berkeley: University of California Press.

Stolzenberg, R.M., Blair-Loy, M. and Waite, L.J. (1995). Religious participation in early adulthood: Age and family life cycle effects on church membership. American Sociological Review 60(1):84-103.

Trinitapoli, J. (2007). The role of religious congregations in the AIDS crisis of subSaharan Africa. [PhD thesis]. Austin: University of Texas at Austin, Department of Sociology.

Trinitapoli, J. (2006). Religious responses to aids in sub-Saharan Africa: An examination of religious congregations in rural Malawi. Review of Religious Research 47(3): 253-270.

Trinitapoli, J., and Regnerus, M.D. (2006). Religion and HIV risk behaviors among married men: Initial results from a study in rural sub-Saharan Africa. Journal for the Scientific Study of Religion 45(4): 505-528.

Williams, L.B. and Zimmer, B.G. (1990). The changing influence of religion on U.S. fertility: Evidence from Rhode Island. Demography 27(3): 475-481.

Zhang, L. (2008). Religious affiliation, religiosity, and male and female fertility. Demographic Research 18(8): 233-262. 
Yeatman \& Trinitapoli: Religion and family planning in rural Malawi 